\section{Nuffield Foundation}

At the time of the Government's takeover of British Leyland the Nuffield Foundation held 25 million shares in the company. These wer eventually disposed of at $10 \mathrm{p}$ each; but, says the Foundation in its annual report for 1975 the reserves built up during the prosperous 1950 s and 1960s meant that its overall financial position remained satisfactory. The repor warns that the inflexibility of academic appoint ments and salary scales is making British universities more rigid. At least one university has asked the Foundation for indemnity against redundancy payments that might become payable to individuals employed on its grants.

\section{Amendments to the BNF}

Detailed amendments to the 1976-78 edition of the British National Formulary were published in the Pharmaceutical Fournal of 16 October. Copies of the amendments are also available on request from the Joint Formulary Committee, BMA House, Tavistock Square, London WC1.

\section{Boots and shoes for the disabled}

Mrs Margery Thornton, the clothing adviser to the Disabled Living Foundation, has collected together information about footwear designed for the disabled and where to get it in Britain. The 44 page foolscap dossier is available from the DLF, 346 Kensington High Street, London W1, price 75 p.

\section{COMING EVENTS}

King's Fund Centre-Patients and staff meeting 16 December, London. Details from the Centre, 126 Albert Street, London NW1 7NF. (Tel 01267 6111.)

Royal College of Psychiatrists-Details of forthcoming meetings of the Psychotherapy Specialist Section are now available from the College, 17 Belgrave Square, London SW IX 8PG. (Tel 01-235 2351-5.)

Devon and Exeter Medical Society-Details and copies of the programme for the session 1976-7 are now available from $\mathrm{Dr} \mathrm{C} \mathrm{H}$ Stewart-Hess, Cheriton Fitzpaine, Crediton, Devon EX17 4HR. (Tel Cheriton Fitzpaine 495.)

Society for Drug Research-Meeting "Drugs used in diseases of skin," 4 January, London. Details from Dr Alma B Simmonds, 35 Summerland Grange, Summerland Gardens, London N10 3QP. (Tel 01-883 6114.)

Institute of Urology-Symposium "Infertility treatment of the husband," 15 January, London. For details see advertisement at $\mathrm{p} \mathrm{x}$.

South Essex Postgraduate Medical CentreDetails of the programme January to April 1977 are now available from the Centre, Basildon Hospital, Nether Mayne, Basildon, Essex SS16 5NL. (Tel 02683911 ext 3360.)

\section{SOCIETIES AND LECTURES}

For attending lectures marked * a fee is charged or a ticket is required. Applications should be made first to the

\section{Monday 6 December}

INSTITUTE OF NeURology-1.15 pm, Professor J H
Quastel, FRS (Canada): Anaesthetics and cerebral transport processes.
Tuesday, 7 December

InSTITUTE OF DeRmatology-4.30 pm, Dr R Eady The ultrastructure of the epidermis.

Royal College of Surgeons of ENGland-4.30 pm Arnott demonstration by $\mathrm{Mr}$ A Levene: Anatomica features of the origin and spread of cancer.

BTMS: R M M

Wednesday, 8 December

Royal Free Hospital - 5 pm, Dr J M Walshe: Wilson's disease.

\section{Thursday, 9 December}

Royal College of Surgeons of England- $5 \mathrm{pm}$ Bradshaw lecture by $\mathrm{Mr}$ Selwyn Taylor: Thyroid medullary carcinoma: a new endocrine syndrome.

ROYAL INFIRMARY, EDINBURGH -5 pm, Honyman
Gillespie lecture by Dr A B Kay: The eosinophil leucocyte: formation, function, and fate.

\section{BMA NOTICES}

\section{Diary of Central Meetings}

\section{DECEMBE}

7 Tues Scottish Hospital Junior Staffs Committe 9 Thurs (7 Drumsheugh Gardens, Edinburgh), 2 pm. 15 Wed Negotiating Subcommittee (CCHMS), 10 $15 \mathrm{Wed}$ Finance and General Purposes Committee $9.30 \mathrm{am}$.

16 Thurs General Medical Services Committee, 16 Thurs Executive Subcommittee (CCHMS), 10.30 21 Tues $\quad$ Scottish General Medical Services Com$10.30 \mathrm{am}$.
$22 \mathrm{Wed}$ Council, $10 \mathrm{am}$.

Division Meetings to be Held

Members proposing to attend meetings marked * are asked to notify in advance the honorary secretary concerned.

Barnet and Finchley-At Finchley Memoria Hospital, Wednesday, 8 December, $8.15 \mathrm{pm}$, meeting to

Blackpool-At Savoy Hotel, Wednesday, 8 Decem ber, 7.30 for $8.45 \mathrm{pm}$, dinner lecture, speaker $\mathrm{Mr} \mathrm{M}$ S Owen.

Cambridge and Isle of Ely-At Addenbrooke' Hospital New Site, Wednesday, 8 December, 8 pm, agm followed by talk by Dr E Brian Lewis: "The problem and difficulties

Durham-At Dryburn Hospital, Monday, 6 December, 8.30 pm, speaker from the Durham County Fire Brigade: "Fires and fire prevention." (Preceded by supper 7 for $7.30 \mathrm{pm}, *$ guests are invited.)

Greenwich-At Greenwich District Hospital, Tuesay, 7 December, 7.30 for $8 \mathrm{pm}$, clinical meeting.

Holland/Lincs-At Pilgrim Hospital, Saturday, 11 December, 7.30 pm, Dr P Barbor: "Neoplasia in Ipswich-At Ipswich Hospital, Wednesday, 8 December, $8.30 \mathrm{pm}$, meeting. (Preceded by supper, $7.30 \mathrm{pm}$.)

Isle of Wight-At Wheatsheaf Hotel, Saturday, 11 December, 8.15 for 8.45 pm, annual dinner.

Manchester-At Boyd House, Saturday, 11 Decemer, 7.30 for $8 \mathrm{pm}$, Christmas party.*

North Warwickshire-At Chase Hotel, Nuneaton, Tuesday, 7 December, 7.30 for $8 \mathrm{pm}$, dinner lecture, peaker Chief Inspector B E Fisher: "The Moorgate (at

yospital, Friday, Salop-At Copthorne tasting.*

December, $7.30 \mathrm{pm}$, agm and lecture by Dr RE Altounyan on his work with asthma.

Solihull-At Marston Green Hospital, Friday, 10 December, $7 \mathrm{pm}$, wine tasting followed by meeting on medical care in various countries and a discussion on

South Bedfordshire-At the Winston Churchil Dunstable, Wednesday, 8 December, $8 \mathrm{pm}$, agm an South Middlesex-At Ashford Hospital, Monday, 6 December, $8.30 \mathrm{pm}$, agm.

West Berkshire-At Royal Berkshire Hospital, Wednesday, 8 December, $8.30 \mathrm{pm}, \mathrm{Mr}$ C R Sandison: "Medical finances in an inflationary period." (Wives ar welcome.

\section{UNIVERSITIES AND COLLEGES}

\section{CAMBRIDGE}

Professor R M Acheson has had the degrees of $M D$ and DSc conferred on him by incorporation.

MD-J R Kemm, J F Smyth.

ABERDEEN

Dr C R Dundas has been appointed senior lecture in surgery (anaesthesia) from 9 January, 1977.

GLASGOW

MD-R Mitchell, R O Quin, P J Rooney, R F M Wood.
LONDON

The title of professor of immunology has been conferred on Dr H Festenstein at the Lond

LIVERPOOL Dr R M R Barnes has been appointed senior lecturer

DUNDEE

Dr J Campbell Murdoch has been appointed senior J

ROYAL COLLEGE OF PHYSICIANS OF AINBURGH

At a quarterly meeting of the college held on 4 Novem-

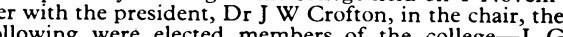
Collee, W B McN Howie, D Jackson, D college-J G ROYAL COLLEGE OF PHYSICIANS AND SURGEONS OF GLASGOW

At the annual meeting held on 1 November the following office-bearers were elected: Professor T Gibson (president); Dr Gavin B Shaw (visitor); Dr Norman MacKay (honorary secretary); $\mathrm{Mr}$ Colin Mackay (honorary (heasurer); Sir Charles Illingworth (honorary librarian) Medical Council); Professor James Ireland (representa tive on the General Dental Council); Dr C D Forbes, Macnaughton, DrR B Wilson, Dr R Hume, Dr Brian O Williams (councillors)

\section{APPOINTMENTS}

Birmingham Area Health Authority (Teaching)Dr S M Mostafa (consultant anaesthetist).

Manchester ARea Health Authority (Tfaching)The following consultants have been appointedDr I E Burton (haematologist); Dr A Merriman (geriatric medicine); Dr T A White (anaesthetist).

NORTH-EAST THAMES RHA-The following consultants have been appointed: Dr C H W Browne (anaesthetist) Offen (general surgery)

NORTH-WESTERN RHA-The following consultants hre been appointed: $\mathrm{Dr} \mathrm{D} \mathrm{N}$ Foster (medicine) (paediatrics); Mr C D Baumber (general surgery); Dr G S Bhatt (psychiatry); Dr S Jegarajah (medicine
with special interest in chest diseases); Mr P L Bali ophthalmology); Mr M S Bell (orthopaedic surgery).

\section{Corrections}

\section{The Week}

When Dr Cameron's speech in Liverpool was quoted in The Week (27 November, p 1336) we regret that a line was omitted from the quotation. The last sentence of the first paragraph should have read:

But it might not always work: indeed, many doctors felt that-and I quote- "to go down the TUC road would be to destroy for ever the standing of doctors in the community; that it would provide the sirongest ammunition for those at present engaged in an insidious campaign to 'cut the doctors down to size.',

\section{Notice to authors}

When original articles and letters for publication are not submitted exclusively to the British Medical fournal this must be stated. For detailed instructions to authors see page 6 of the issue dated 3 January 1976.

Correspondence on editorial business should be addressed to the Editor, British Medical fournal, BMA House, Tavistock Square, London WC1H 9JR. Telephone: 01-387 4499. Telegrams Aitiology, London WC1. Communications will not be acknowledged unless a stamped addressed postcard or an international reply coupon is enclosed.

Authors wanting reprints of their articles should notify the Publishing Manager, BMA House, Tavistock Square, WC1H 9JR, on receipt of proofs.

\section{British Medical Journal 1976}

All Rights Reserved. No part of this publication may be reproduced, stored in a retrieval system, or transmitted, in any form or by any means, electronic, mechanical, photocopying, recording or otherwise, without the prior permission of the British Medical fournal. 